\title{
The Impact of Group and Network on Welfare: Finding of Gender Identity in The Urban Informal Sector In East Flood Canal (BKT), Jakarta
}

\author{
Beti Nurbaiti ${ }^{1}$, Chotib $^{2}$ \\ \{bettysigit@gmail.com¹; chotib@hotmail.com²\} \\ ${ }^{1}$ Universitas Bhayangkara Jakarta Raya, ${ }^{2}$ Universitas Indonesia
}

\begin{abstract}
This study aims to see the extent to which Group and Network affect the welfare of street vendors in terms of gender identity in the East Flood Canal area, Jakarta. From the results of surveys in the field, this Group and Network is one of the dimensions that constitute social capital, which are proved to be a supporting factor for trade in the BKT region, and affect the welfare of street vendors. The results also show that there is a significant influence between the Group and Network on welfare, and there is no difference between male and female street vendors in gaining the opportunity to acquire skills or knowledge of trading, material assistance and moral support during trading.
\end{abstract}

Keywords: Gender Identity, Urban Informal Sector, Group and Network, Welfare, East Flood Canal.

\section{Introduction}

Development often sacrifice the livelihoods of rural communities as farmers, where agricultural land and plantations turn into industry, housing, and even hotels and golf courses. To meet the necessities of life, with all the limitations of education and capital, humans try to carry out economic activities according to their capabilities. In this case, the informal sector is most substantial container providing these needs. People are willing to migrate from the area of origin to improve their standard of living in the destination[1], and [2]. One of the informal sectors that drives the community's economy are street vendors in the Jakarta Flood Canal area (BKT area). The street vendors who run these business are simple, do not need a business establishment permit, tax exempt. With limited capital, they sell people's daily needs[3], [4], and [5].

BKT area always crowded with visitors on weekdays and holidays, providing snacks and food, even clothes, watches, tire patches, and other daily necessities at affordable prices. This area is also a place to hang out for all ages. During Monday to Friday, this location is visited from $4 \mathrm{pm}$, and more and more crowded at 5 to $6 \mathrm{pm}$, when the workers coming home from work. The location is closed at $1 \mathrm{am}$. On weekend, the area is busier than usual, even closed until morning before dawn. Based on the phenomena above, the BKT is an exciting location to study, related to the role of the Group and Network that fills the lives of street vendors in daily life, as well as to further examine aspects of existing gender identity. 


\section{Literature Review}

The existence of industrial development, business centers, and the increasing population of the population to an area in the era of globalization occurred in the city center [6], and [7]. So it is not surprising if there is a steady flow of migration from rural to urban areas, especially in developing countries, because of the imbalance of development between rural villages. The city promises a better life than a village. Migration is one of one's efforts to improve his standard of living, and not only affects the population size of an area, but also has a significant influence on the socioeconomic aspects [8].

In principle, business can develop in areas with more population, and have purchasing power [9]. The migration of urban village residents has been so massive with the advancement of transportation technology, then businesses are developing in urban areas in the informal sector [10] and [11]. The informal sector is a dynamic sector, continues to grow and is always able to adapt to the development of the economic climate. Decent work is central to poverty alleviation efforts and how to create equitable development and sustainable development, fulfilling basic human rights [12]. Generally, informal work is self-employed, recruiting family members or close relatives, family workers, where the production is limited to household needs, but also suitable for sale according to community needs [13]. The informal sector answers this as a form of adaptation from oversupply of labor that is not absorbed by the market swerved into entrepreneurship in the sector [14]. The informal sector was chosen because it has flexibility in carrying out entrepreneurial activities even for beginners [15].

Migrant workers can survive in relationships by maintaining interpersonal relationships, friendship, and close family ties where they provide information to each other, which unites one another, which is often called social capital [16]. According to [17], social capital consists of 3 groups, namely: (1) Input Dimension, (Group and Network, also Trust and Solidarity); (2) Operational Dimension, (Collective Action and Cooperation) ; and (3) Implementation dimension, (Social Cohesion and Inclusion, also Empowerment).

The group and network sub-dimensions include aspects of participation, contributions and, informal networking and individual involvement in the social entity, while the trust and solidarity sub-dimension describes perceptions and attitudes of trust towards neighbours, public policymakers, and helps between members as time goes by [18]. The essence of social capital is the existence of networks, applied norms, and trust and solidarity between individuals in social entities. Social capital is conducive in increasing the productivity of individuals and communities in carrying out daily activities such as working and trading and other social activities [19].

Social capital is often cited as a factor in the progress of economic activity in society can be increase the accumulation of money capital/goods, homeownership, or business capital within the framework of kinship and mutual trust. Social capital, in the form of community ties, has stronger relationships that will be able to overcome the use of other people who harm themselves in doing business. Besides, economic transaction costs can be reduced in the purchase of production inputs such as land, technology, and raw materials to increase profits more. Another advantage of strong ties in the community is being able to improve welfare by facilitating greater collaboration, such as giving loans to fellow members based on mutual trust [20].

In most developing countries, opportunities for doing business often have gaps between men and women, and most of the findings are that men have the chance to create, try to be higher than women. It can be achieved through collaboration based on group approaches and networking among women workers [21]. Nowadays, the role of women shifts not only to take 
care of household affairs, also to make a living outside the home. for example in Africa women are able to trade up to the border regions of the country with driving his own car as a means of transportation and transporting merchandise as street vendors [22]. Through a group and network approach, women can solve problems related to capital to the completion of domestic work because of their dual role that requires working outside the home in addition to the essential part of doing household work [23].

Welfare could be measured by income, consumption or family expenses, living conditions, housing facilities, health of family members, easy access to health services, ease of getting educational facilities, and transportation facilities. Also, well-being also characterized by prosperity, happiness and, satisfaction in life [24]. According to [25] welfare, is measured in two aspects, namely (1) the objective aspects, wherein this case welfare is measured through material and (2) subjective aspects, where welfare is the intimate experience of each other than material. Physical elements include: income or income, wealth, expenditure/consumption, living conditions, and education, health, while the subjective aspects include psychological, social, and spiritual well-being. Individual elements are generally related to one's ability to have a balanced lifestyle, to have interpersonal relationships, social networks and community support, as well as to have a relationship with God and proper worship.

\section{Research Methodology}

The study was conducted for one month from mid-July to mid-August 2019 in the BKT Jakarta area by taking primary data using a questionnaire instrument from 300 respondents. When taking primary data, researchers also conducted in-depth interviews with respondents randomly. The results of the field data that has been processed with Lisrel software. This process carried out through 3 (three) stages, namely: (1) Test the measurement model that includes the Goodness of Fit Index (GOFI) test, validity, and reliability test. For the GOFI test can be seen in the table where there are nine indicators to show a good match (RMSEA, NFI, NNFI, CFI, IFI, RFI, Standardized RMR, GFI, and AGFI). For Perfect Fit contains degree of freedom =0, minimum fit function chi-square $=0$. For the validity test can be seen from the Standardized Loading Factor (SLF) value $>0.50$, and the reliability test is said to be good if the Construct Reliability value $(\mathrm{CR})>0.70$, and Variance Extract $(\mathrm{VE})>0.50$. For further, (2) Confirmatory Factor Analysis (CFA) test, and the last one is (3) Structural model test (hypothesis test), with absolute $t$ value score $>1.96$ for accepted hypothesis [26].

\section{Results and Discussion}

The measurement test data processing results can be seen in the description below: 


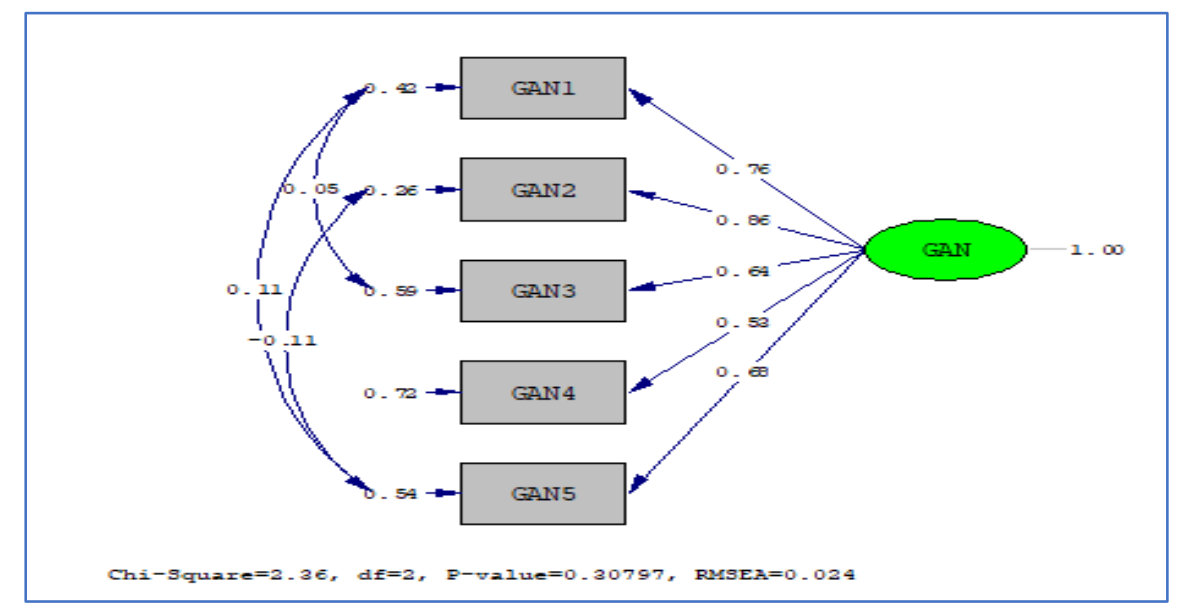

Fig. 1. Path Diagram Variable Group and Network (GAN)

(Standardized Solution)

Table 1. Goodness of Fit Test Results Group and Network (GAN)

\begin{tabular}{cccc}
\hline Indicator & Good Fit & Goodness of Fit Test Results & Information \\
\hline RMSEA & $\leq 0.08$ & 0.024 & Good Fit \\
NFI & $\geq 0.90$ & 1.00 & Good Fit \\
NNFI & $\geq 0.90$ & 1.00 & Good Fit \\
CFI & $\geq 0.90$ & 1.00 & Good Fit \\
IFI & $\geq 0.90$ & 1.00 & Good Fit \\
RFI & $\geq 0.90$ & 0.98 & Good Fit \\
Standardized RMR & $\leq 0.05$ & 0.015 & Good Fit \\
GFI & $\geq 0.90$ & 1.00 & Good Fit \\
AGFI & $\geq 0.90$ & 0.97 & Good Fit \\
\hline
\end{tabular}

Conclusion Goodness of Fit Test Results: has a good match, the data support the research model.

Table 2. Validity and Reliability of Group and Network (GAN)

\begin{tabular}{cccc}
\hline $\begin{array}{c}\text { Latent Variable/ } \\
\text { Observed Variable }\end{array}$ & $\begin{array}{c}\text { Standardized } \\
\text { Loading Factor } \\
\text { (SLF) }\end{array}$ & Error & Information \\
\hline GAN1 & 0.76 & 0.42 & Good Validity \\
GAN2 & 0.86 & 0.36 & Good Validity \\
GAN3 & 0.64 & 0.59 & Good Validity \\
GAN4 & 0.53 & 0.72 & Good Validity \\
GAN5 & 0.66 & 0.54 & Good Validity \\
\hline
\end{tabular}

Conclusion Goodness: all variables have good validity and reliability, with values $\mathrm{CR}=$

$0.82, \mathrm{VE}=0.50$ 
All measurement results of the five observed variables from the latent variable Group and Network (GAN) valid, because the SLF value > 0.50 with the highest order of SLF values to the low are GAN2, GAN1, GAN5, GAN3, and GAN4. Based on the highest SLF value, it can be seen that the ease of obtaining the knowledge of trading in groups due to kinship and becomes the main thing in the findings in the field (GAN2), followed by the ease of getting capital (GAN1), ease of getting moral and material assistance (GAN5), ease of developing a business (GAN3) and ease of solving problems in trading (GAN4). The migrant traders in BKT based on the results of interviews stated that they gained knowledge about how to start and run a trading business in a group that is still related by family, or one of their hometown colleagues. Besides, with the kinship, capital problems can also be overcome by cooperation among members of the kinship. They trust one another, making it easier to help one another and motivate morally and materially. In terms of developing their business, example opening a branch of trade, they have more confidence in members who still have a kinship which easier to exercise control especially if there are problems during trading.

These migrants came almost entirely to try their luck in the capital, and were invited by family who had already traded at BKT for years. The kinship factor makes them feel more comfortable. It believes that the skills assistance, capital assistance will be smooth because they have known each other long before. Especially if one hometown, they find more in this kinship, and already feel part of a large family, mainly when surviving in someone else's territory, which is not their home area, even far away from their home region. This continues to be done from generation to generation to form a trade group in BKT. This is in line with research conducted by [18], and [27] where migrant workers / traders in the informal sector can more easily get capital if they are in groups. In addition, according to [19] and those who have a group entity or a tribe are also more supportive to help if there are difficulties in terms of capital, as well as trading skills and information. Another form of interaction is vertically, with individuals/groups outside the community environment (bridging), also with parties who have higher authority, such as government, formal social organizations, business institutions, and so on (linking) [28].

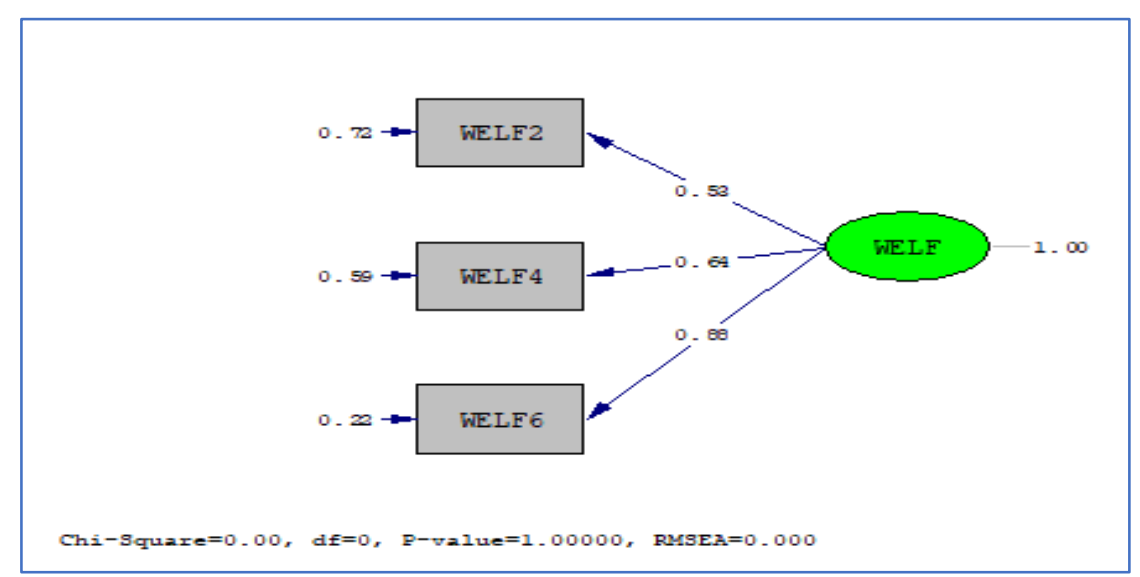

Fig. 2. Path Diagram Variable Welfare (WELF) (Standardized Solution) 
Table 3. Goodness of Fit Test Results Welfare (WELF)

$$
\begin{gathered}
\text { Degree of Freedom }=0 \\
\text { Minimum Fit Function Chi-Square }=0.00(\mathrm{P}=1.00) \\
\text { Normal Theory Weighted Least Square Chi-Square }=0.00(\mathrm{P}=1.00) \\
\text { Satorra-Bentler Scaled Chi-Square }=0.00(\mathrm{P}=1.00) \\
\text { The Model is Saturated, the Fit is Perfect! }
\end{gathered}
$$

Conclusion: all variables observed in the WELF latent variable have a very good fit (Perfect Fit), the data support the research model.

Table 4. Validity and Reliability of Welfare (WELF)

\begin{tabular}{cccc}
\hline $\begin{array}{c}\text { Latent Variable/ } \\
\text { Observed Variable }\end{array}$ & $\begin{array}{c}\text { Standardized } \\
\text { Loading Factor } \\
\text { (SLF) }\end{array}$ & Error & Information \\
\hline WELF2 & 0.53 & 0.72 & Good Validity \\
WELF4 & 0.64 & 0.59 & Good Validity \\
WELF6 & 0.88 & 0.22 & Good Validity \\
\hline
\end{tabular}

Conclusion Goodness : all variables have good validity and reliability, with values $\mathrm{CR}=0.73, \mathrm{VE}=0.50$

Respondents consider that welfare is primarily to have a place to live (WELF6), has time to worship and explore religious knowledge (WELF4) and is able to consume 4 healthy foods 5 ideally or healthy and nutritious food (WELF2). Meeting nutrition is felt to be far more important than having to go to a doctor or hospital. These three things are considered more priority compared to the time of friendship with family / relatives, as well as time to improve trading skills. This finding is in line with research conducted by ${ }^{[24]}$, and ${ }^{[25]}$, where welfare is measured by income marked by decent living conditions, and nutrition fulfilment.

In theory, there is objective welfare (material) and subjective well-being (non-material). Based on the results of the data in the field also supplemented with interviews, migrant traders in BKT prioritize the fulfilment of nutrition, in this case, healthy food first as their primary welfare standard. After nutrition had fulfilled, the next priority is the time they have to worship, study religion, and be busy with their trade. After that, they thought that a decent place to live was able to protect family members from the heat and rain, even though the place of residence was simple.

Although their average income per month is enough to survive, and there is not much savings, but they do not forget the concept of health and balanced nutrition. There is another exciting thing that the hustle and bustle of metropolitan life in Jakarta does not make them forget 
their religion and spiritual life. Also this religious aspect is considered far more important than a decent place to live, not getting rained and overheated even though it is a simple contract.

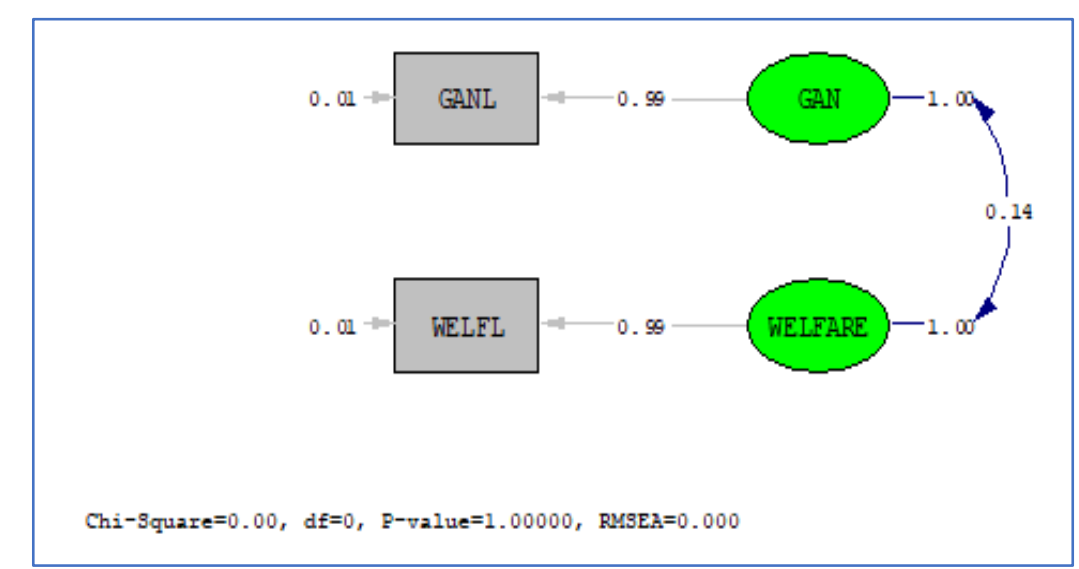

Fig. 3. Path Diagram of Confirmatory Factor Analysis (CFA) Test (Standardized Solution)

Table 5.Confirmatory Factor Analysis (CFA) Test

Degree of Freedom $=0$

Minimum Fit Function Chi-Square $=0.00(\mathrm{P}=1.00)$

Normal Theory Weighted Least Square Chi-Square $=0.00(\mathrm{P}=1.00)$

Satorra-Bentler Scaled Chi-Square $=0.00(\mathrm{P}=1.00)$

The Model is Saturated, the Fit is Perfect!

Conclusion of CFA Test: all variables observed have a very good fit (Perfect Fit), the data support the research model.

Table 6. Validity and Reliability of CFA Test

\begin{tabular}{|c|c|c|c|}
\hline $\begin{array}{l}\text { Latent Variable/ } \\
\text { Observed Variable }\end{array}$ & $\begin{array}{l}\text { Standardized } \\
\text { Loading Factor } \\
(\mathrm{SLF})\end{array}$ & Error & Information \\
\hline$G A N$ & \multirow{4}{*}{$\begin{array}{r}\mathrm{CR}= \\
\mathrm{VE}= \\
0.99\end{array}$} & \multirow{3}{*}{0.01} & Good Reliability \\
\hline GANL & & & Good Validity \\
\hline WELF & & & Good Reliability \\
\hline WELF & & 0.01 & Good Reliability \\
\hline
\end{tabular}




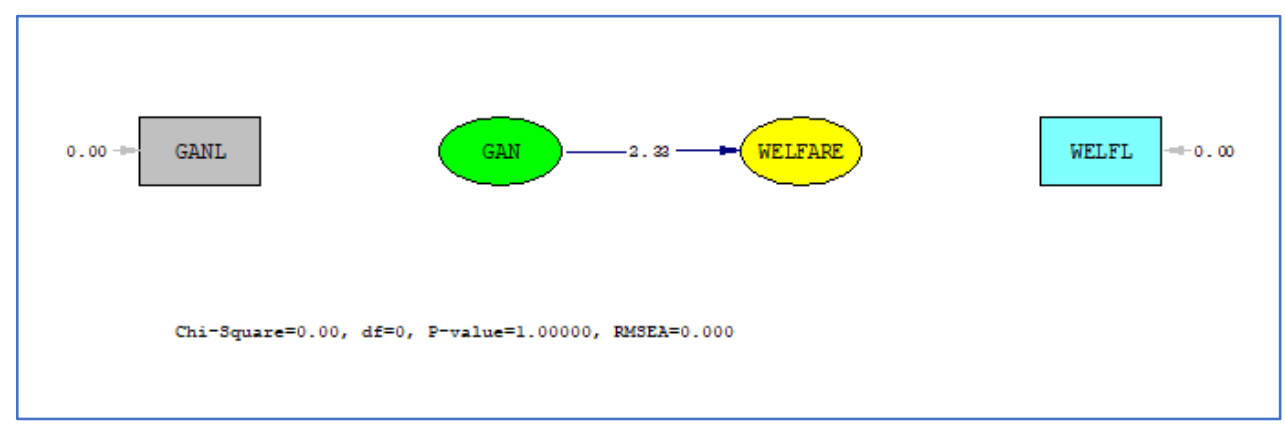

Fig. 4. Path Diagram Of Measurement Model Test (T-Value)

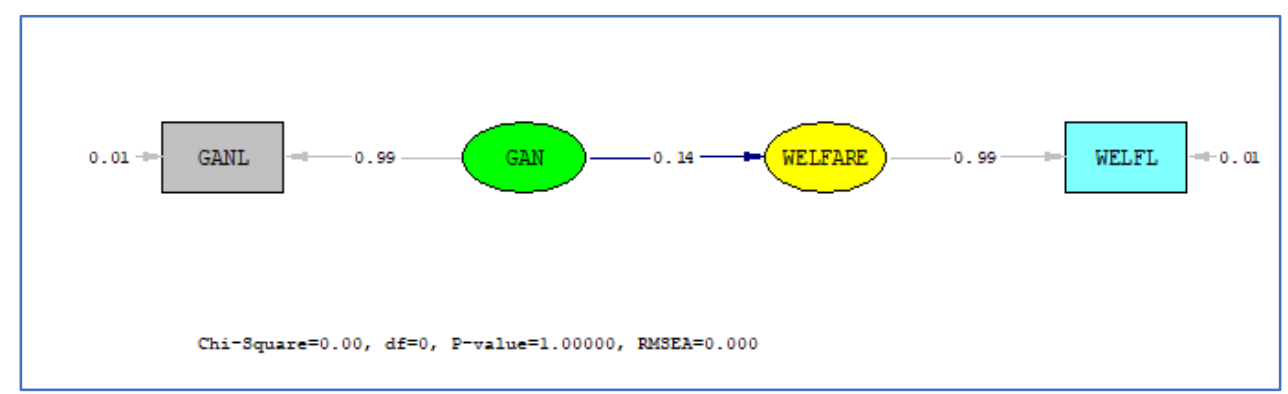

Fig. 5. Path Diagram of Test Measurement Model

(Standard Coefficient)

Table 7. Structural Model Test Results

\begin{tabular}{|c|c|c|c|c|}
\hline Information & $\begin{array}{c}\text { Relationship } \\
\text { Between } \\
\text { Variables } \\
\end{array}$ & $\begin{array}{l}\text { T-Value } \\
\text { Score }\end{array}$ & $\begin{array}{c}\text { Standard } \\
\text { Coefficient } \\
\text { Score }\end{array}$ & $\begin{array}{l}\text { Hypothesis } \\
\text { Test Results }\end{array}$ \\
\hline Hypothesis 1 & $\begin{array}{l}\text { There is a } \\
\text { significant } \\
\text { relationship } \\
\text { between Group } \\
\text { and Network } \\
\text { (GAN) on } \\
\text { Welfare } \\
\text { (WELF) } \\
\text { variables }\end{array}$ & 2.33 & 0.14 & $\begin{array}{c}\text { Hypothesis } 1 \\
\text { was accepted, } \\
\text { T value } \geq 1.96, \\
\text { positively } \\
\text { correlated }\end{array}$ \\
\hline
\end{tabular}

Based on the results of the structural model test below, it is proven the research question that there is a significant relationship/correlation between Group and Network (GAN) and the welfare of workers/migrants in urban areas, namely Jakarta. Statistically indicated by the T- 
Value of 2.33 which higher than 1.96. It can be seen the profile of respondents of migrant traders in BKT in terms of sex, age, and education as follows:

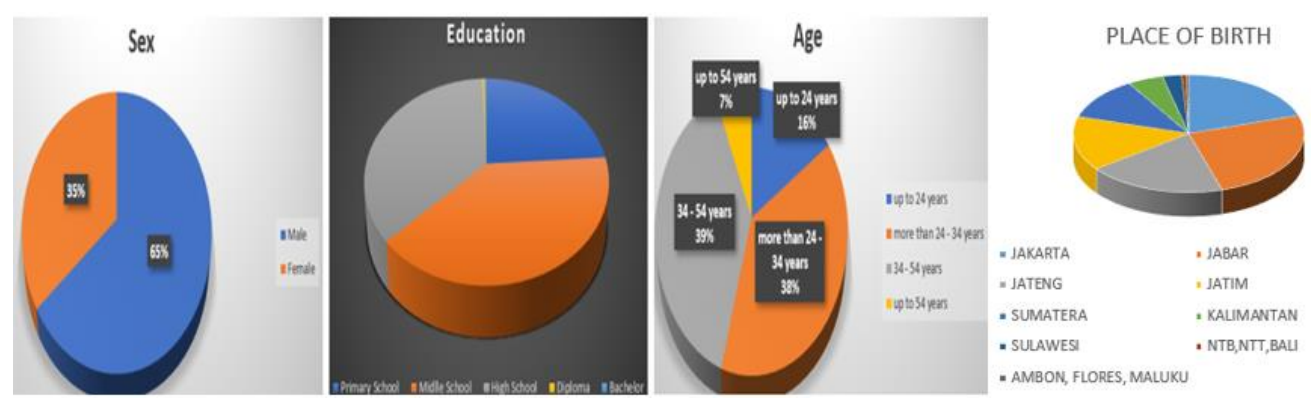

Fig. 6. Pie Chart of Descriptive Statistics Results From The Respondent's Profile

Based on the survey data obtained that male migrant traders are greater than women, with the majority of middle school and high school education levels, and the most at the age of 24 to 54 years. As additional information based on the results of the interview, the migrant traders in the BKT have been around for quite a long time, most of them coming from West Java, East Java, Central Java, and Sumatra. Besides, there are also those from Kalimantan and Sulawesi and also NTT, NTB, Bali, Papua, Maluku, and Flores, although only a few. In line with the results of research from [29], metropolitan is a relatively large urban area in terms of space, population and scale of economic and social activities, one of which is the city of Jakarta. This has become an attraction for people to come to metropolitan cities, leaving their hometown/ birth in the hope of improving their standard of living through the informal sector with entrepreneurship. The decision to become an entrepreneur or worker is related to an individual's attitude to risk, managerial ability, family background, and financial constraints [30].

The young female workers tend to experience work informality compared to male workers. The young educated workers tend to experience work informality compared to highly educated workers, and young workers in rural areas tend to experience work informality compared to urban areas. And there is a tendency that young workers who do not experience migration tend to experience work informality compared to those who migrate. Based on age, people who are in the productive age category (15-49 years) are the most migratory groups. The highest migration pattern occurs at the age of 30 - 50 years and will decrease with age at the age of up to 50 years. This is in line with research conducted by [31] and [32]. 
Table 8. Anova Test Result

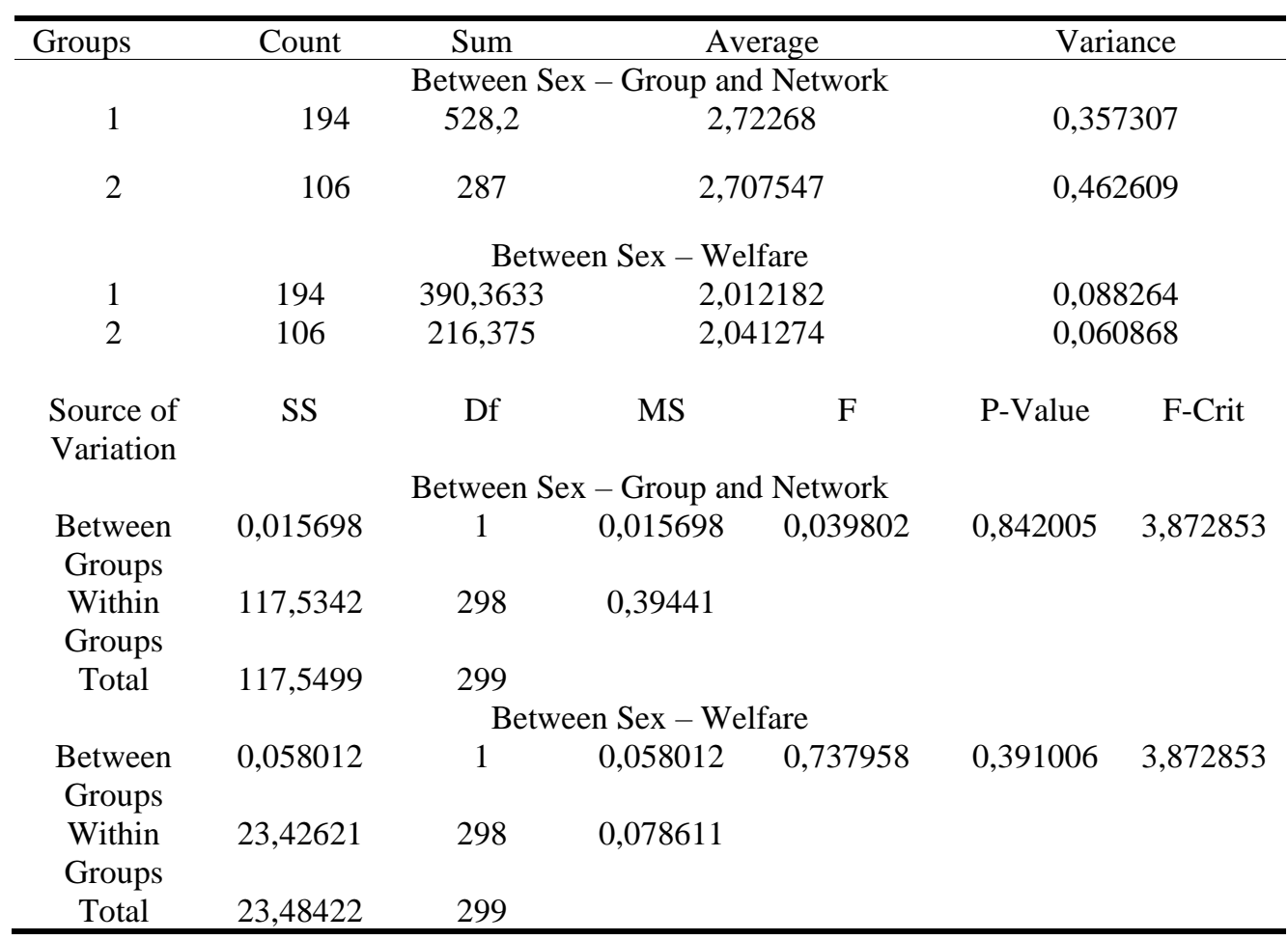

Based on the ANOVA test results in the picture above, it appears that there is no significant difference between male and female street vendors, both in terms of opportunities to develop themselves through the Group and Network, to the condition of their welfare. This statistically proven that for the two variables mentioned above, GAN and WELF, the P value in the ANOVA test is entirely above 0.05 . Although the number of respondents is 300 , there are more street vendors than men, this has no effect on opportunities to advance and gain opportunities in trading, improve skills be concluded access to capital in trading. It can be concluded that in terms of gender identity, there is no gender inequality, and there has been a gender equality in actualizing themselves outside the home, as a street vendor in BKT. The survey results on street vendors in BKT show that gender equality in trading has long been naturally occurring, where the driving factor is the fulfilment of household economic needs, both for daily life, eating, drinking, shelter, as well as education and health for themselves and their family members. The above mentioned research findings are supported by the results of previous studies by [33], [34] and [35].

In accordance with the results of research from [33], empowering women is easier to do through the Group And Network approach than individuals. Through a group approach, it is easier for women to gain access to trading opportunities, venture capital, and mutual assistance if there is trouble. Research conducted by [34] as time goes by, more and more women have the opportunity to develop themselves outside the home, such as trading and working. In this regard, 
gender discrimination has increasingly disappeared over time, and there has been increasing gender equality in developing countries.

The role of men who also help with household affairs, contributes to the advancement of opportunities for women to work and work outside the home. In a society that practices such matters, it is of the opinion that men and women have the same equality and equality of rights and obligations, hand in hand to meet the needs of the household as well as domestic work within it [35].

\section{Conclusion}

Based on the results of a survey of 300 street vendors at BKT Jakarta, there are findings that the Group and Network aspects are very important and are felt to be significant in reducing the burden of capital, knowledge / trading skills as well as other difficulties for individuals and families. Most street vendors are not native citizens of Jakarta, but are dominated by migrants from West Java, Central Java and East Java. Limitations of formal education for trading, can be overcome in the Group and Network approach. As such, Group and Network becomes a determining factor for the welfare the life of street vendors in BKT.

No gender discrimination was found related to business opportunities, gaining trade skills, as well as access to capital for both male and female street vendors in BKT. This shows that, despite the average level of education of the respondents middle school and high school education levels, they are already aware of gender equality.

\section{References}

[1] Nurbaiti, Beti. 2017. Pengaruh Status Migrasi Melalui Karakteristik Sosiodemografi Terhadap Tingkat Kesejahteraan Pekerja di DKI Jakarta. Jurnal Kajian Ilmiah Universitas Bhayangkara Jakarta Raya, 17 (2).

[2] Beegle, K. De Weerdt, J., and Dercon, S. 2011. Migration and Economic Mobility In Tanzania: Evidence From a Tracking Survey. Review of Economics and Statistics, 93(3), pp. 1010-1033.

[3] Kourtit, Karima and Peter Nijkamp. 2012. Strangers on The Move: Ethnic Entrepreneurs as Urban Change Actors. European Review, Vol. 20, No 3, pp. 376-402. Academia Europe.

[4] Mahanani, W. and Chotib. 2018. The Influence of Collective Action, Community, Empowerment, and Shared Vision to The Community Capacity in Urban Water Resource Conservation. IOP Conference Series Earth Environmental Science.

[5] Putnam, Robert. D. 2013. Making Democracy Work: Civic Tradition In Modern Italy. Princeton University Press, New Jersey.

[6] Schoonjans, B. Van Cauwenberge, P., Van Der Bauwhede, H. 2013. "Formal Business Networking and SME Growth". Small Business Economics, 42. 169-181.

[7] William and Lansky. 2013. Informal Employment In developed And Developing Economies: Perspectives and Policy Responses. International Labour Review, Vo. 152, No. 3-4, pp. 355-380.

[8] Chotib and Nurbaiti. 2018. Are Migrant Workers in DKI Jakarta More Welfare Than Non Migrants? A Data Analysis of SUSENAS 2013. Journal of Strategic and Global Studies 1 (1), pp. 15-28.

[9] Horiuchi, S. Kanazawa Y, Suzuki, T. and Takikawa H. 2013. Who Gain Resources From Which Social Capital? A Mathematical Review In Social Capital: Theory, Measurement and Outcome, Nova Publisher pp. 3 - 28.

[10] Horiuchi, S. and Takashi T. 2016. Globalization and Regional Revitalization in A Local University of Japan. In: Globalization, Economic, Political and Social Issues. Nova Publisher, pp. 149 - 159.

[11] Bappenas. 2009. Peran Sektor Informal Sebagai Katup Pengaman Masalah Ketenagakerjaan. Bappenas, Jakarta. 
[12] International Labour Organization (ILO). 2012. Decent Work Profile in Indonesia. Geneva, International Labour Office.

[13] Chen, Martha Alter. 2012. The Informal Economy ; Definitions, Theories and Policies. USA, WIEGO.

[14] Morris, Jeremy. 2011. Socially Embedded Workers at The Nexus of Diverse Work in Rusia. International Journal Sociology and Social Policy, Vol. 31. No 11/12. Pp. 619-631.

[15] Priyono, Edi. 2015. Memahami Pasar Tenaga Kerja. Pustaka Lentera, Jakarta.

[16] Walsh, Kieran and Isabel Shutes. 2016. Care Relationships, Quality and Care and Migrant Working Caring for Older People. National University of Ireland Galway, London School of Economics and Political Science, UK.

[17] Narayan, D. and Michael F. Cassidy. 2014. A Dimensional Approach to Measuring Social Capital: Development and Validation Of A Social Capital Inventory. Current Sociology, SAGE Publication. London, Thousand Oaks, CA and New Delhi., Vol. 29 (2): 59 - 102.

[18] Um, Seong Gee. 2012. At The Bottom: Migrant Workers in The South Korean Long - Term Care Market. University of Toronto.

[19] Kwok, Steve and Leung Chan. 2015. Segregation Dimensions and Development Differentials of Ethnic Enclave. Journal Sociology and Social Policy, Vol. 42. No 1. Pp. 82 - 96.

[20] Santareli, Enrico and Hien Thu Tran. 2013. The Interplay of Human and Social Capital in Shaping Entrepreneurial Performance: The Case of Vietnam. Small Business Economics 40, 435 - 458.

[21] Ogando, et al. 2017. Gender and Informal Livelihoods: Coping Strategies and Perceptions of Waste Pickers In Sub Sahara Africa and Latin America. International Journal of Sociology and Social Policy, Vol. 37 no7/8, Emerald Publishing Limited.

[22] Muzvidziwa, V.N. 2015. Gender Nature of Informal Cross border Trade In Zimbabwe. Journal of Social Development in Africa, Vol. 30, No. 1, January 2015.

[23] Vassen, et al. 2014. The Effect of Microcredit On Women's Control Over Household Spending In Developing Countries: A Systematic Review And Meta Analysis. Campbell Systematic Reviews. The Campbell Collaboration.

[24] Schueller and Seligman. 2010. Pursuit of Pleasure, Engagement, and Meaning: Relationships to Subjective and Objective Measure of Well Being. The Journal of Positive Psychology. Vol. 5, No. 4, pp. 253-263.

[25] Alatartseva, E. and Barysheva, G. 2015. Well-being: Subjective and Objective Aspects. ProcediaSocia and Behavioural Sciences, 166, pp 36-42.

[26] Wijanto, Setyo H 2008 Structural Equation Modelling dengan Lisrel 8.8, Konsep dan Tutorial Graha Ilmu, Yogyakarta.

[27] Wells, Jill and Arthur Jason. 2010. Employment Relationship and Organizing Strategies In The Informal Construction Sector. African Studies Quarterly. Vol 11, Issues 2\&3, Spring 2010.

[28] Badan Pusat Statistik. 2013. Statistik Modal Sosial Tahun 2012. Jakarta.

[29] Handiyatmo, D. 2009. Penggunaan Jenis Transportasi Oleh Pelaku Mobilitas Ulang Alik di Enam Kawasan Metropolitan (Analisis data SUPAS 2005).

[30] Catherine, Y. Ira N gang and Myeong Su Yun. 2012. Self Employment and Wage Earning: Hungary During Transition. IZA Discussion Paper No 572.

[31] William, Collin C. and Youseff, Youssef. 2015. Classifying Latin American Economies: A Degree of Informalisation Approach. International Journal of Business Administration. Vol. 5, No. 3.

[32] Chaudary, SR and Barman A. 2014. Holistic Model of Subjective Well Being A Proposed Model and Exploration of Content. Zenith International Journal of Multidiscipline Research. ISSN 2231-5780. Vol. 4 (3).

[33] Pawbe, Wayack et al. 2014. Relationship Between Woman's Socioeconomic Status And Empowerment In Barkina Faso: A Focus On Participation In Decision Making and Experience Of Domestic Violence. African Population Studies Vol. 28, No. 2. Supplement July 2014.

[34] Al Shami, et al. 2018. The Effect Of Microcredit On Women Empowerment In Welfare and Decision Making In Malaysia. Springer Science and Business Media.

[35] Meah, Angela. 2014. Reconceptualing Power and Gender Subjective In Domestic Cooking Space. SAGE, Progress In Human Geography. 